\title{
Valor da ciência, defesa do conhecimento e Perspectival Realism: Entrevista com Michela Massimi
}

\author{
Value of science, defense of knowledge and perspective \\ Realism: Interview with Michela Massimi
}

\author{
Prof ${ }^{a}$ Dra. Michela Massimi - University of Edinburgh \\ michela.massimi@ed.ac.uk \\ https://orcid.org/0000-0001-6626-9174
}

Prof. Dr. Vinícius Carvalho da Silva (VCS) - Physikós/FACH/UFMS

vinicius c silva@gmail.com

https://orcid.org/0000-0002-1061-2727

Prof. Dr. Ivã Gurgel - TeHCo/IF-USP

gurgel@usp.br

https://orcid.org/0000-0003-4968-6907

Ronaldo Moraca (RM) Physikós/FACH/UFMS

romoraca@bol.com.br

https://orcid.org/0000-0002-6878-0280//

Recebido em: 08/10/2021

Aceito em:11/10/2021

Michela Massimi é professora de Filosofia da Ciência no Departamento de Filosofia da Universidade de Edimburgo, onde também é afiliada ao Higgs Centre for Theoretical Physics. Membro de importantes sociedades filosóficas e científicas, como a Royal Society of Edinburgh, a Royal Astronomical Society, e a Académie Internationale de Philosophie des Sciences (membro correspondente) é presidente eleita da PSA, Philosophy of Science Association, para o biênio 20232024. Massimi, com dupla nacionalidade, italiana e britânica, estudou na Sapienza Università di Roma, na London School of Economics, e lecionou História e Filosofia da Ciência na University College London antes de mudar-se para Edimburgo. Massimi trabalha com Filosofia da Ciência em uma abordagem marcada pelo recurso à pesquisa histórica. Seus interesses amplos abarcam a Filosofia da Cosmologia, o realismo científico, os estudos de ciências, as relações entre ciência e sociedade, entre outros tópicos. Tem se destacado por defender o que chama de Perspectival Realism, se afastando tanto do realismo tradicional, quanto do pragmatismo e do relativismo. Nessa entrevista dialogamos com Massimi sobre temas como o valor da ciência, a defesa da ciência em épocas de negacionismo e obscurantismo e as características de sua posição filosófica. 
VCS: Gostaríamos de começar com uma questão ampla e tradicional, mas que se tornou muito atual no contexto em que vivemos. Esta é a questão central deste dossiê: Qual é o valor da ciência? Como essa questão é tratada na filosofia hoje?

Michela Massimi: Esta é uma questão muito importante e que continua a atrair a atenção dos filósofos. Nos preocupamos com a ciência por uma série de razões diferentes: por exemplo, nos preocupamos em investir em ciência e tecnologia porque a própria qualidade de vida em nossas sociedades depende dos avanços científicos. Se alguém precisava de um lembrete desta verdade mundana, a atual pandemia de COVID-19 chamou a atenção para a importância de investir em pesquisas biomédicas para novas vacinas e tratamentos para este novo vírus. Os filósofos da ciência tradicionalmente respondem à pergunta sobre o valor da ciência apontando a importância das evidências científicas, dos fatos científicos, dos métodos estatísticos e das técnicas de modelagem por trás da produção confiável de conhecimento científico. Além disso, mais e mais nos dias de hoje os filósofos da ciência também estão fazendo a pergunta inversa, ou seja, que tipo de valores estão em jogo na pesquisa científica. Existe todo um ramo da filosofia da ciência que leva o nome de "ciência e valores" e que aborda precisamente essas questões, ou seja, não apenas qual o valor da ciência, mas também como entender a frequentemente complexa interrelação entre ciência e valores.

\section{IG: Como você situa o perspectivismo nas discussões sobre ciência hoje? Podemos considerá-lo uma tentativa de reconciliar as diferentes correntes de pensamento existentes na Filosofia, na História e nos Estudos Sociais das Ciências?}

Michela Massimi: Vejo o perspectivismo como uma postura filosófica que, de certa forma, envolve debates de longa data sobre o realismo na ciência, ao mesmo tempo em que aceita algumas lições vindas da História da Ciência. Em suma, a questão filosófica que me interessa é a seguinte: como alguém pode ser realista sobre a ciência quando se aprende a lição que vem da História da Ciência de que as teorias científicas vêm e vão com o tempo, que os conceitos científicos mudam com o tempo e assim por diante? A monografia que estou terminando de escrever (intitulada Perspectival Realism - a ser publicada pela Oxford University Press, EUA, no final de 2021) se esforça para responder a essa pergunta. ElA articula o tipo de realismo que considero compatível com a ideia perspectivista de que o conhecimento científico é sempre situado histórica e culturalmente, de que é o conhecimento produzido por uma pluralidade de comunidades epistêmicas ao longo do tempo e entre culturas.

RM: Aproveitando os temas abordados no livro "Compreendendo o Perspectivismo: Desafios Científicos e Perspectivas Metodológicas"' (2019), faço uma pergunta de fundamento: Existe uma tese principal que distingue o perspectivismo do pragmatismo e relativismo?

Michela Massimi: Esta é uma ótima questão, que sempre me perguntam. Então aqui está a resposta. Considero 'perspectivismo' a visão de que o conhecimento científico é sempre o conhecimento de comunidades epistémicas situadas histórica e culturalmente. Assim, o perspectivismo ${ }^{2}$ compartilha com o pragmatismo a ênfase nos agentes humanos (ou, como prefiro chamá-los, comunidades epistêmicas, uma vez que o conhecimento científico nunca é produto de um único agente humano). Perspectivismo (ou melhor, o que chamo de "perspectival realism") difere do pragmatismo porque endossa elementos realistas que geralmente (nem sempre) estão ausentes em pontos de vista que se autodenominam "pragmatistas": a saber, (1) uma "teoria da verdade por correspondência" e (2) a ideia de representação científica. Obviamente, tenho que contar uma história um pouco diferente do realismo científico tradicional para (1) e (2), a fim de reconciliá-los com o pluralismo sobre as perspectivas científicas (algo que atendo na monografia Perspectival Realism). Quando se trata de relativismo, é claro que existem diferentes variedades de relativismo (algumas são muito distantes do perspectivismo). Mas

2 Para saber mais sobre o perspectival realism defendido por Massimi ver: $<<$ https://www.perspectivalrealism.org/ $>>$. 
pode-se ver algumas semelhanças entre a ideia 3 de uma pluralidade de perspectivas científicas e o apelo do relativista epistêmico a uma pluralidade de sistemas epistêmicos, por exemplo. No entanto, o perspectivismo (ou melhor, o perspectival realism) não é relativismo epistêmico porque (i) não relativiza a verdade às perspectivas científicas (lembre-se, afinal, eu defendo uma (1) "teoria da verdade por correspondência": ser verdadeiro é corresponder à forma como as coisas são no mundo, independentemente de nós); e (ii) o perspectival realism vê as perspectivas científicas em diálogo para produzir conhecimento científico confiável ao longo do tempo (ao invés de alegações de conhecimento científico serem incompatíveis entre si, e cada um preso nas restrições de seu próprio sistema epistêmico, como o relativismo epistêmico normalmente faz).

VCS: Há um debate na História e Filosofia da Ciência e nos estudos de ciências, entre duas concepções, que poderíamos chamar de "concepção normativa" e "concepção descritiva". Como você vê esse debate entre descrição e prescrição? O perspectivismo, como você o entende, pode nos oferecer uma solução em algum sentido?

Michela Massimi: Esta é outra grande e difícil questão ao mesmo tempo. O tipo de Filosofia da Ciência em que trabalho é muito inspirado pela atenção dada à História da Ciência e à prática científica. Assim, a este respeito, há um importante componente "descritivo" no projeto do perspectival realism. Existe um componente normativo também? É sempre problemático falar de um "componente normativo" quando se trata de pontos de vista em Filosofia da Ciência, eu penso. A normatividade vem com a suposição de que existe uma maneira como as coisas deveriam ser. E eu, por exemplo, não vejo nosso trabalho como filósofos da ciência como o de pontificar cientistas (ou outros filósofos ou historiadores e assim por diante) sobre como as coisas deveriam ser. Assim, não vejo o realismo perspectivo em si como uma prescrição normativa de como a ciência deveria ser, mas mais como uma descrição de como é feita, uma vez que prestemos atenção suficiente à natureza perspectiva da investigação científica e da produção do conhecimento científico. O problema é, porém, que muitas vezes esquecemos ou negligenciamos em prestar atenção à natureza pluralista e perspectiva da investigação científica. Freqüentemente, apresentamos visões filosóficas como o realismo como se estivéssemos ocupando algum ponto de vista neutro a partir do qual falamos sobre ciência; ou como se a ciência fosse uma questão de vencedores e perdedores, sobre qual paradigma científico venceu e qual paradigma científico historicamente perdeu a batalha (pense em Kuhn sobre as revoluções científicas). Eu gostaria que o perspectival realism nos motivasse a pensar sobre o conhecimento científico de uma forma pluralista genuína que não caia em nenhum desses dois modelos. E, em meu livro, ofereço argumentos e uma riqueza de exemplos e estudos de casos históricos e da prática da ciência nesse sentido. Isso conta como uma dimensão normativa? Pode ser; contanto que tomemos a palavra "normativo" com cautela e não com o mesmo sentido de "a maneira como as coisas deveriam ser".

RM: Surpreende você que, no século 21, exista um movimento coordenado por líderes políticos e influenciadores digitais que pretendem negar as evidências científicas?

Michela Massimi: Mais do que surpreender, me entristece profundamente e me preocupa que haja tanta negação de evidências científicas e fatos científicos e desconfiança na perícia científica em alguns setores importantes. Voltando à primeira questão, podemos ver, neste caso, os efeitos perigosos de poderosos valores sócio-político-econômicos em jogo em parcelas de sociedades em determinados momentos históricos. E acredito que os filósofos da ciência compartilham com os cientistas o dever de se levantar e falar em defesa das evidências científicas e dos fatos científicos sempre que alguém espalha desinformação, falsidades e teorias da conspiração contra a ciência.

IG: Você é membro de associações importantes e é presidente eleita da Philosophy of Science Association (PSA). Como você vê o papel dessas instituições e quais são os desafios e projetos para a próxima década? 
Michela Massimi: Sinto-me profundamente honrada em humildemente servir à comunidade internacional de filósofos da ciência em minha função como presidente eleita da Philosophy of Science Association (PSA). Acho que o PSA cresceu notavelmente na última década e fez um trabalho realmente incrível em termos de promoção de uma comunidade de pesquisa cada vez mais diversificada. Pessoalmente, adoraria ver este trabalho continuar e expandir nos próximos anos. Espero sinceramente que os filósofos da ciência em todo o mundo - onde quer que estejam - vejam a PSA como uma comunidade acolhedora e diversa, com a qual eles possam querer se envolver cada vez mais. E farei o máximo em colaboração com o Conselho de Administração para garantir que a PSA crie mais oportunidades de servir - dentro de sua missão e atividades - colegas em todo o mundo, não apenas na América do Norte e na Europa. Acabamos de lançar, por exemplo, um novo site (https://www.philsci.org/) onde é possível aos filósofos da ciência que são membros da PSA desempenharem um papel ativo e se oferecerem como voluntários para servir em vários comitês da PSA, para envolver-se com as comunidades membros da PSA e assim por diante (além de participar das Conferências Bienais da PSA, da PSA's Women Caucus ${ }^{3}$ atividades de mentoria por Underrepresented Philosophy of Science Scholars UPSS ${ }^{4}$, entre outros). E eu encorajaria muito os colegas a se voluntariarem para todas essas atividades: esta é a sua PSA, ao seu serviço, onde quer que você esteja. Este é apenas o primeiro passo de mais iniciativas destinadas a promover a inclusão e a diversidade nos próximos anos.

$* * *$

Inglês

Michela Massimi is a professor of Philosophy of Science in the Department of Philosophy at the University of Edinburgh, where she is also affiliated with the Higgs Center for Theoretical Physics. Member of important philosophical and scientific societies, such as the Royal Society of Edinburgh, the Royal Astronomical Society, and the Académie Internationale de Philosophie des Sciences (corresponding member), she is elected president of the PSA, Philosophy of Science Association, for the 2023-2024 biennium. Massimi, with dual nationality, Italian and British, studied at Sapienza Università di Roma, London School of Economics, and was professor of History and Philosophy of Science at University College London before moving to Edinburgh. Massimi works with Philosophy of Science in an approach marked by the use of historical research. His broad interests include Philosophy of Cosmology, scientific realism, science studies, the relationship between science and society, among other topics. It has stood out for defending what it calls Perspectival Realism, moving away from both traditional realism, pragmatism and relativism. In this interview we spoke with Massimi on topics such as the value of science, the defense of science in times of negation and obscurantism and the characteristics of his philosophical position.

VCS: We would like to start with a broad and traditional question, but that has become very current in the context in which we live. This is the central question of this dossier: What is the value of science? How is this question handled in philosophy today?

Michela Massimi: This is a very important question and one that continues to attract philosophers' attention. We care about science for a number of different reasons: for example, we care about investing in science and technology because the very quality of life in our societies depend on scientific advancements. If anyone needed a reminder of this mundane truth, the current COVID-19 pandemic has drawn attention to the importance of investing in biomedical research for new vaccines and treatments for this new virus. Philosophers of science have traditionally answered the question about the value of science by pointing out the importance of scientific evidence, scientific facts, statistical methods, and modelling techniques behind reliable and trustworthy scientific knowledge production. In addition to it, more and more these days philosophers

3 Ver em $<<$ https://www.philsci.org/womens_caucus.php $>>$

4 Ver em $<<$ https://philsci.org/upss_mentoring_program.php $>>$ 
of science are also asking the converse question, namely what kind of values are at play in scientific research. There is an entire branch of philosophy of science that goes under the name of "science and values" and that tackles precisely these issues, i.e. not just what value science is, but also how to understand the often complex inter-relation between science and values.

IG: How do you situate perspectivism in discussions about science today? Could we consider it an attempt to reconcile different currents of thought existing in Philosophy, History and Social Studies of Sciences?

Michela Massimi: I see perspectivism as a philosophical stance that in a way engages long-standing debates about realism in science while also taking on board some lessons coming from the history of science. In brief, the philosophical question that interests me is the following one: how can one be realist about science when one takes on board the lesson coming from the history of science that scientific theories come and go over time, that scientific concepts change over time and so on? The monograph I am finishing to write (entitled Perspectival Realism - and forthcoming with Oxford University Press, USA, in late 2021) endeavors to answer this question. It articulates the kind of realism that I see compatible with the perspectival idea that scientific knowledge is always historically and culturally situated, it is knowledge produced by a plurality of epistemic communities over time and across cultures.

RM: Taking advantage of the themes covered in the book "Understanding Perspectivism: Scientific Challenges and Methodological Prospects" (2019) I ask a question about foundation level: Is there a main thesis that distinguishes perspectivism from pragmatism and relativism?

Michela Massimi: This is a great question and one I get often asked about. So here is the answer. I take 'perspectivism' to be the view that scientific knowledge is always knowledge of historically and culturally situated epistemic communities. As such, perspectivism shares with pragmatism the emphasis on human agents (or as I prefer to call them, epistemic communities since scientific knowledge is never the product of a single human agent). Perspectivism (or better, what I call 'perspectival realism') differs from pragmatism in that it endorses realist elements that are usually (not always) absent in views that style themselves as 'pragmatist': namely, (1) a 'correspondence theory of truth' and (2) the idea of scientific representation. I have obviously to give a slightly different story than traditional scientific realism to both (1) and (2) so as to reconcile them with pluralism about scientific perspectives (something I attend to in the monograph Perspectival realism). When it comes to relativism, of course there are different varieties of relativism (some are very remote from perspectivism). But one might see some similarities between the 3 idea of a plurality of scientific perspectives and the epistemic relativist's appeal to a plurality of epistemic systems for example. However, perspectivism (or better, perspectival realism) is not epistemic relativism because (i) it does not relativise truth to scientific perspectives (recall, after all, I defend a (1) 'correspondence theory of truth': to be true is to correspond to the way things are in the world, independently of us); and (ii) perspectival realism sees scientific perspectives in dialogue to produce reliable scientific knowledge over time (rather than scientific knowledge claims being incompatible with one another, and each trapped into the strictures of its own epistemic system, as epistemic relativism would typically have it).

VCS: There is a debate in History and Philosophy of Science and in science studies, between two conceptions, which we could call "normative conception" and "descriptive conception". How do you see this debate between description and prescription? Can perspectivism, as you understand it, offer us a solution in some sense?

Michela Massimi: This is another great and difficult question at the same time. The kind of philosophy of science I work on is very much inspired by attention to the history of science and scientific practice. Thus, 
in this respect, there is an important 'descriptive' component to the project of perspectival realism. Is there a normative component too? It is always problematic to speak of a 'normative component' when it comes to views in philosophy of science, I think. Normativity comes with the assumption that there is a way things ought to be like. And I, for one, do not see our job as philosophers of science as that of pontifying scientists (or other fellow philosophers or historians and so on) about the way things ought to be like. Thus, I do not see perspectival realism itself as a normative description of the way science ought to be, but more as a description of how it is done once we pay sufficient attention to the perspectival nature of scientific inquiry and scientific knowledge production. The problem is, though, that often we overlook or neglect to pay attention to the pluralist and perspectival nature of scientific inquiry. Often we present philosophical views such as realism as if we were occupying some neutral standpoint from which to talk about science; or as if science was a matter of winners and losers, which scientific paradigm won, and which scientific paradigm historically lost the battle (think of Kuhn on scientific revolutions). I'd like perspectival realism to entice us to think about scientific knowledge in a genuine pluralist way that does not fall back onto either of these two templates. And, in my book, I offer arguments and a wealth of examples and case studies from the history and practice of science to this effect. Does that count as a normative dimension? Maybe; as long as we take the word 'normative'with caution and not as interchangeable with "the way things ought to be like".

RM: Does surprise you that, in the 21 st century, there is a movement coordinated by political leaders and digital influencers who intend to deny scientific evidence?

Michela Massimi: More than surprising, it profoundly saddens me and worries me that there is such denial of scientific evidence and scientific facts and mistrust in scientific expertise in some prominent quarters. Going back to the first question, one can see in this case the dangerous effects of powerful socio-political-economical values at play in pockets of societies at particular historical times. And I believe philosophers of science share with scientists a duty to stand up and speak up in defense of scientific evidence and scientific facts any time anyone spreads misinformation, falsehoods, and conspiracy theories against science.

IG: You are a member of important associations and are President-Elect of the Philosophy of Science Association (PSA). How do you see the role of these institutions and what are the challenges and projects for the next decade?

Michela Massimi: I am honored and deeply humbled to serve the international community of philosophers of science in my role as President-Elect of the Philosophy of Science Association (PSA). I think the PSA has grown remarkably over the past decade and has done some really terrific work in terms of fostering a more and more diverse research community. Personally, I would love to see this work to continue and expand in the years ahead. I very much hope that philosophers of science around the world - wherever they are-will see the PSA as a welcoming and diverse community, one with whom they might want to engage more and more. And I will do my utmost in collaboration with the 5 Governing Board to make sure the PSA creates more opportunities to serve-within its mission and activities-colleagues around the world, not just in North America and Europe. We have just launched for example a new website (https://www.philsci.org/) where it is possible for philosophers of science who are PSA members to take an active role and volunteer to serve on a number of PSA committees, to engage with PSA member communities and so on (in addition to taking part in the PSA Biennial Conferences, PSA's Women Caucus and mentoring activities by the Underrepresented Philosophy of Science Scholars UPSS, among others). And I would very much encourage colleagues to volunteer for all these activities: this is your PSA at your service, wherever you are based. This is just the first step of more initiatives designed to foster inclusivity and diversity in the years ahead. 